\title{
Does Sticky Cost Behavior Affect Earnings Quality? Evidence From Egypt
}

\author{
Mohamed Aly Wahdan \\ Professor, Faculty of Commerce, Menoufia University, Egypt \\ Ashraf Khalifa Ahmed \\ Lecturer, Accounting Department, Menoufia University, Egypt \\ Marwa Saber Hamoda Alsayed (Corresponding author) \\ Lecturer, Accounting Department, Menoufia University, Egypt \\ E-mail: marwa.saber@commerce.menofia.edu.eg
}

Received: May 11, 2021

doi: 10.5296/ijafr.v11i2.18634
Accepted: June 19, 2021

Published: June 23, 2021

URL: https://doi.org/10.5296/ijafr.v11i2.18634

\begin{abstract}
This paper seeks to extend the literature on cost behavior by providing additional evidence on sticky cost behavior in developing countries namely Egypt. Moreover, it aims to determine to what extent sticky cost behavior affects earnings quality. The paper depends on a sample consists of 38 listed firms in the Egyptian Exchange over the period from 2004 to 2017. The findings reveal that total costs respond asymmetrically to the equivalent change in sales in six of the nine examined sectors. Furthermore, both patterns of sticky cost behavior, stickiness and anti-stickiness, negatively affect earnings quality. Therefore, managers, investors, and managerial accountants should take into account sticky cost behavior when making their decisions. This study contributes to the stream of research that integrates managerial accounting with financial accounting by combining sticky cost behavior with earnings quality. In addition, it extends the line of research related to the impacts of sticky cost behavior. Moreover, it gives new evidence on sticky cost behavior and its impacts from one of emerging countries.
\end{abstract}

Keywords: Cost behavior, Cost stickiness, Cost anti-stickiness, Earnings quality 


\section{Introduction}

Understanding and realizing how costs behave is very considerable especially for managers and managerial accountants since they depend on numerous techniques that require the analysis of cost behavior such as cost-volume-profit analysis. Therefore, the proper understanding of cost behavior enables to correctly evaluate manufacturing methods and take convenient decisions especially that related to marketing and production over short and long terms. Recently, there has been tremendous argument about the essential assumption of cost behavior which is related to the relationship between costs and the activity volume. This assumption alleges that the relationship between change in costs and the activity level is always symmetric or proportional without taking into account the direction of this change. A novel approach of thinking in cost behavior refuted this assumption and proved that some costs change asymmetrically with the change in activity level. This approach has been called "sticky cost behavior". Sticky cost behavior includes two patterns of cost behavior which are cost stickiness and cost anti-stickiness. Cost stickiness means that costs respond to the increase in sales more than their response to the equivalent decrease in sales (Anderson et al. 2003), while cost anti-stickiness denotes that costs respond to the increase in sales less than their response to the equivalent decrease in sales (Weiss, 2010).

Taking sticky cost behavior into account besides the symmetrical model of cost behavior is crucial to accurately understand how costs behave. For example, if investors and analysts realize that cost behavior does not always take the linear form as symmetrical cost model presumes, it is expected that earnings forecast precision will be promoted particularly in the case of sales decrease. This is what the study of Ciftci et al. (2016) proved when examining if the correct understanding of cost behavior leads to raising the accuracy of analysts' earnings forecasts. Similarly, cost and managerial accountants should take into account the non-linearity of cost behavior when using techniques like cost budgeting to estimate costs accurately (Yao, 2018) and provide correct estimates of the current and new products. Likewise, managers will be more able to make appropriate decisions especially decisions related to allocating resources and manage costs depending on the real status.

The majority of the literature related to sticky cost behavior has been conducted to test the existence of sticky cost behavior and its determinants (e.g., Chen et al., 2012; Kama and Weiss, 2013; Cannon, 2014; Holzhacker et al., 2015; Kitching et al., 2016; Cohen et al., 2017; Kwon, 2018; Parbowo et al., 2018; Chung et al., 2019; Gray, 2020). These studies concluded that some kinds of costs display asymmetric responses towards changes in activity level asserting the prevalence of sticky cost behavior. Furthermore, these studies found that the key cause of sticky cost behavior is the managerial decisions toward changes in current demand compared to previous and future demand. Moreover, these managerial decisions are influenced by some factors such as adjustment costs, current capacity utilization, and the direction of prior-period sales. Nonetheless, these studies addressed one or two types of costs without examining the existence of sticky cost behavior in total costs although total costs alleviate managerial choices except Chung et al. (2019) and Hassanein and Younis (2020).

A few studies of sticky cost behavior have attempted to investigate the implications of this 
behavior. Inside this stream, some studies have started to combine sticky cost behavior with financial accounting topics. A good example of these studies is the two studies carried out by Banker et al. (2016) and Fourati et al. (2020) to identify the effect of sticky cost behavior on accounting conservatism. One of the crucial topics in financial accounting is earnings quality. Earnings quality is very important not only for academic researchers but also for all users of financial statements. This is because earnings are considered as a milestone in evaluating prior and present performance as well as predicting performance in the next periods. Furthermore, earnings figure plays a key role in the contractual agreements throughout ratios and metrics extracted from them (Kamarudin and Ismail, 2014; De Sousa and Galdi, 2016). Consequently, the higher level of earnings quality enables firms to increase the effectiveness of managerial and investment decisions.

Accordingly, this paper seeks to achieve two main objectives. The first is to provide additional evidence of the existence of sticky cost behavior among Egyptian sectors. The second is to find out the impact of the both patterns of sticky cost behavior on earnings quality. The findings indicate that sticky cost behavior is prevalent across six sectors in the Egyptian Exchange. Furthermore, cost stickiness negatively affects the level of earnings quality and the earnings quality level is more accurate after controlling for the impact of cost stickiness. In the same vein, cost anti-stickiness has a negative impact on earnings quality; nonetheless, the magnitude of this impact is tiny.

The current paper contributes to several lines of research. Firstly, this study expands the line of research on sticky cost behavior by providing evidence from emerging economies, particularly in the light of limited studies in the Egyptian environment. Secondly, this study is enriched the literature stream related to the implications of sticky cost behavior which contains few studies. Thirdly, the study contributes to the line of research that merges managerial accounting with financial accounting by combining sticky cost behavior with earnings quality. Therefore, earnings quality literature also will witness a novel line of research by examining how sticky cost behavior affects earnings quality. Fourthly, to the best of the researchers' knowledge, this the first study that examined the impact of sticky cost behavior on earnings quality from informative viewpoint in the Egyptian environment. Finally, on the contrary to most of the empirical studies regarding sticky cost behavior, this study paid the same attention to anti-sticky behavior in contrast to most of the empirical studies concerning sticky cost behavior.

The remainder of this paper is organized as follows. Section 2 reviews the literature of sticky cost behavior and presents hypotheses development. Section 3 displays the research methodology. Section 4 demonstrates results accompanied by a discussion. Section 5 shows the robustness analysis. Section 6 exhibits the conclusion.

\section{Literature Review and Hypotheses Development}

\subsection{Evidence on Sticky Cost Behavior}

The study of Anderson et al. (2003) is considered as the seminal study in this research area as it presented a clear model to define the disproportional response of costs to activity level 


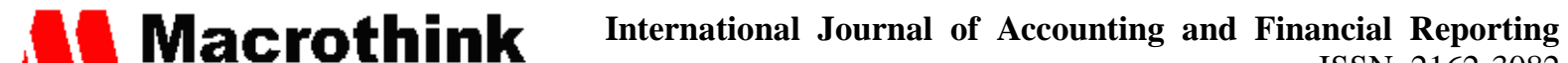 ISSN 2162-3082 2021, Vol. 11, No. 2}

changes. In addition, it is the first study that labeled the disproportional response of costs towards changes in activity level by "Sticky". Anderson et al. (2003) tested the cost behavior of selling, general, and administrative costs using data for 7629 American firms during the period from 1979 to 1998 . They concluded that costs rise by $0.55 \%$ and decline by $0.35 \%$ when sales increase and decrease per $1 \%$ which contradicts the symmetric cost behavior. Therefore, Anderson et al. (2003) has opened up new avenues to conduct more researches concerning sticky cost behavior and its determinants.

Banker and Byzalov (2014) presented more evidence of sticky cost behavior on an international basis as they utilized a sample of 315,967 firm-years among 20 countries over the period from 1988 to 2008 . The study proved that sticky cost behavior is a global concept because cost stickiness appeared in 16 countries of 20 countries. In Italy, Dalla Via and Perego (2014) provided empirical evidence on sticky cost behavior by analyzing a sample of Italian listed firms from 1999 to 2008. The study expanded the concept of sticky cost behavior by testing different types of costs. The study showed that the cost of goods sold and operating costs display anti-stickiness in their behavior, whereas labor cost shows stickiness in its behavior. Surprisingly, the cost behavior of selling, general, and administrative costs contradicts the result of Anderson et al. (2003) and does not exhibit cost stickiness.

In the same context, Venieris et al. (2015) explored the cost behavior of selling, general, and administrative costs and the influence of organization capital on sticky cost behavior by using a sample of 55,769 firm-year observations of US-listed firms. The study found that firms with high organization capital display stickiness in cost behavior, whereas firms with low organization capital show anti-stickiness in cost behavior. Subramaniam and Watson (2016) provided further evidence on cost stickiness of two kinds of costs, which are selling, general, and administrative costs and cost of goods sold, across four industries which are manufacturing, merchandising, services, and financial firms. The study concluded a crucial result which is sticky cost behavior is an industry-specific whether in the magnitude of activity changes that causes sticky cost behavior or in the determinants that direct this behavior.

Uy (2016) proved the existence of sticky cost behavior in the Philippines depending on a sample of 76 firms during the period from 2000 to 2012. The study found that the cost of goods sold demonstrates cost stickiness since it increases by $0.41 \%$ but decline by 0.01 for a $1 \%$ increase and decrease in sales. Also, operating costs display cost stickiness as they rise nearly by $0.27 \%$ but diminish approximately by $0.11 \%$ when sales increase and decrease by $1 \%$. Sticky cost behavior cannot be observed in investment costs. In Greece, Cohen et al. (2017) tried to explore if sticky cost behavior can occur in local governments. The study proved that sticky cost behavior can be observed in local governments as administrative and public relation expenses showed anti-sticky behavior. The results of the study assert that political incentives can play an essential role in the occurrence of sticky cost behavior.

To investigate the cost behavior of other types of costs, Cheung et al. (2019) investigated the cost behavior of research and development costs, which is not commonly used in the literature, among Korean listed firms. The findings of the study revealed that research and 


\section{Macrothink Interational Jornal of Acesenting and Finactil Reporting ISSN 2162-3082 2021, Vol. 11, No. 2}

development costs do not show sticky cost behavior. However, these costs display sticky cost behavior when controlling for a successive decrease in sales, performance, and economic growth. Further, Gray (2020) analyzed the cost behavior of operating lease expenses. The findings concluded that operating lease expenses display cost stickiness as they rise by $0.891 \%$ per $1 \%$ increase in sales, but they decline by $0.116 \%$ per $1 \%$ decrease in sales.

In the same vein, Hassanein and Younis (2020) examined sticky cost behavior before, during, and after the financial crisis in the U.K chemical industry by using the cost behavior of six kinds of costs. The most important result of the study is that the behavior of the same type of cost is not permanent because it can change from one period to another according to economic conditions. For instance, selling, general, and administrative costs generally display cost stickiness. However, when dividing the sample period, selling, general, and administrative costs show cost stickiness pre and post the financial crisis, but they do not show any asymmetric response during the financial crisis. Also, the cost of goods sold exhibits cost stickiness in general. Nonetheless, it changes to cost anti-stickiness after the financial crisis when splitting the sample period.

\subsection{The Existence of Sticky Cost Behavior in Egypt}

Some attempts have been made to investigate the existence of sticky cost behavior in the Egyptian environment. For example, Ezat (2014) examined how the cost of goods sold respond to changes in activity level by using 89 Egyptian listed firms from 2009 to 2013. The findings demonstrated that the cost of goods sold exhibits stickiness in its behavior as it increases by $1.1 \%$ but diminishes by $0.95 \%$ when sales increase and decrease by $1 \%$. This result is in line with the results of Uy (2016) and Hassanein and Younis (2020), but it differs from Dalla Via and Perego (2014). Likewise, Ibrahim (2015) introduced additional evidence on the prevalence of sticky cost behavior among Egyptian firms by relying on three types of costs from 2004 to 2011. These costs were selling, general, and administrative costs, cost of goods sold, and operating costs.

In the same context, Ibrahim and Ezat (2017) explored the cost behavior of selling, general, and administrative costs, cost of goods sold, and total costs which is the combined value of the prior two costs. Moreover, the study aimed to analyze the impact of issuing corporate governance code on sticky cost behavior. The findings of the study indicated that selling, general, and administrative costs show cost stickiness. After the application of the corporate governance law, selling, general, and administrative costs convert from stickiness to anti-stickiness. Also, the study found that the cost of goods sold displays sticky behavior even post applying the corporate governance law. It is worth mentioning that Ibrahim and Ezat (2017) found that the stickiness degree of the cost of goods sold increases significantly after applying the corporate governance law. Furthermore, total costs exhibit cost stickiness pre and post applying the corporate governance law. In addition, the stickiness degree of total costs is higher post the corporate governance law. Similarly, Ibrahim (2018) tested sticky cost behavior in the Egyptian environment by using the cost of goods sold from 2008 to 2013. Further, the study sought to identify the impact of board characteristics, as one of the corporate governance mechanisms, on sticky cost behavior. The findings indicated that the 
cost of goods sold displays stickiness in its behavior. Additionally, the study concluded that the board size, role duality, and non-executive directors positively affect cost stickiness. Moreover, institutional ownership, as a control variable, alleviates the degree of stickiness.

To sum up, the aforementioned studies in subsections 2.1 and 2.2 shed light on some substantial points. Firstly, sticky cost behavior is a pervasive global concept because it has been observed in various countries such as the United States of America, Italy, Korea, Greece, the United Kingdom, Canada, and Egypt. Secondly, the same kind of cost displays different cost behavior from one study to another. Moreover, the same type of cost behaves differently in the same study when controlling for some economic and legal factors. Finally, sticky cost behavior occurs not only in private firms but also in state-owned firms. The basic limitation of these studies is that they concentrated on one or two types of costs without examining the prevalence of sticky cost behavior in total costs to alleviate managerial choices. Only Chung et al. (2019) and Hassanein and Younis (2020) examined sticky cost behavior by using total costs. Moreover, a limited number of studies were conducted in Arabian countries. Therefore, the current research will examine the existence of sticky cost behavior in total costs among Egyptian sectors. Thus, the first hypothesis can be formulated as follows:

\section{H1. Total costs respond asymmetrically to the equivalent change in sales, i.e., display sticky cost behavior.}

\subsection{The Implications of Sticky Cost Behavior}

Weiss (2010) began a remarkable stream of studies related to finding out the consequences of sticky cost behavior. The study of Weiss (2010) examined the impact of sticky cost behavior on analysts' earnings forecasts by using 44,931 industrial firm quarters for 2,520 firms for the years 1986 to 2005 . The findings of the study revealed that realizing sticky cost behavior increases the accuracy of analysts' earnings forecasts. Furthermore, the study indicated that investors can realize sticky cost behavior in total costs, but it is hard for investors to realize sticky cost behavior in cost components. It is worth mentioning that the study of Weiss (2010) is the first study that presented a novel measure of stickiness degree; moreover, the study provided the concept of anti-sticky behavior which expanded the concept of sticky cost behavior.

Following Weiss (2010), a number of studies have analyzed the implications of sticky cost behavior in different aspects. Regarding earnings forecasts, Bu et al. (2015) investigated the effect of sticky cost behavior on the precision of earnings forecasts. The results concluded that controlling for sticky cost behavior improves the precision of analysts' earnings forecasts. Likewise, Ciftci et al. (2016) attempted to identify if an incorrect understanding of cost behavior results in errors of analysts' earnings forecast. The results found that the correct understanding of cost behavior enables analysts to diminish earnings forecasts errors and thus enhances the accuracy of predicting earnings. Also, some studies (e.g., Ciftci and Salama, 2018; Dai et al. 2018; Han et al., 2020) aimed to investigate the impact of sticky cost behavior on managers' decisions to issue earnings forecasts as a type of voluntary disclosure. These studies inferred that there is a positive relationship between sticky cost behavior and the probability of managerial earnings forecasts issuance. 


\section{Mll Macrothink}

International Journal of Accounting and Financial Reporting

ISSN 2162-3082

2021, Vol. 11, No. 2

In this stream, some studies, the most closely to the current paper, have attempted to merge sticky cost behavior with financial accounting topics. For instance, Banker et al. (2016) tested the impact of cost stickiness on accounting conservatism. The findings indicated that the accounting conservatism estimate is more accurate when controlling for cost stickiness because accounting conservatism estimate displays a 27.2\% upward bias when not controlling for cost stickiness in the model of Basu (1997). As a consequence, it is necessary when estimating accounting conservatism to take cost stickiness into account in order to avoid misrepresented estimation. In the same vein, Fourati et al. (2020) examined how cost stickiness affects accounting conservatism across 18 countries from 1997 to 2015 . The study denoted that ignoring the impact of cost stickiness in the model of Basu (1997) distorts the estimate of accounting conservatism as the study found that accounting conservatism was overvalued by $46.55 \%$ when not controlling for cost stickiness. Moreover, the relation between accounting conservatism and cost stickiness varies among country groups and industries.

In addition, previous studies examined the impact of sticky cost behavior on another aspect of financial accounting which is earnings management. For instance, Silva et al. (2019) investigated the effect of cost stickiness on earnings management among Brazilian firms. The results concluded that cost stickiness has a positive effect on discretionary accruals which is considered an indicator of earnings management practices. Furthermore, the results pointed out that the model of Dechow et al. (1995) should include cost stickiness to estimate discretionary accruals more accurately and hence estimating earnings management correctly.

One limitation of the above-mentioned studies is that they examined the implications of sticky cost behavior on some aspects such as earnings forecasts, accounting conservatism, and earnings management. But these studies did not analyze the implications of sticky cost behavior on earnings quality, particularly from the informative perspective. It is expected that sticky cost behavior will influence earnings quality as a result of the direct relationship between costs and earnings. Another limitation of the aforesaid studies is that they paid great attention to the impacts of cost stickiness, whereas they ignored the impacts of cost anti-stickiness except Weiss (2010) and Ciftci and Salama (2018). Consequently, further studies will be directed to explore the implications of anti-sticky behavior and whether it has the same impact of cost stickiness or not.

\subsubsection{The Effect of Cost Stickiness on Earnings Quality}

According to cost stickiness, costs diminish in the case of sales decrease less than costs increase in the case of sales increase by an equivalent amount. As a consequence, it is expected that earnings are likely to decline as a result of cost stickiness. In other words, cost stickiness will negatively affect the persistence of earnings and thus has a negative impact on earnings quality. The reason of this negative expectation is that managers retain unutilized resources when sales diminish in the case of cost stickiness. This retention of unutilized resources increases the level of costs and decreases the level of earnings. Thus, the decline in earnings level lowers the ability of current earnings to be sustained which leads to a decrease in earnings persistence and hence a decrease in earnings quality. Figure (1) summarizes how 


\section{Al Macrothink \\ International Journal of Accounting and Financial Reporting

cost stickiness affects earnings quality.

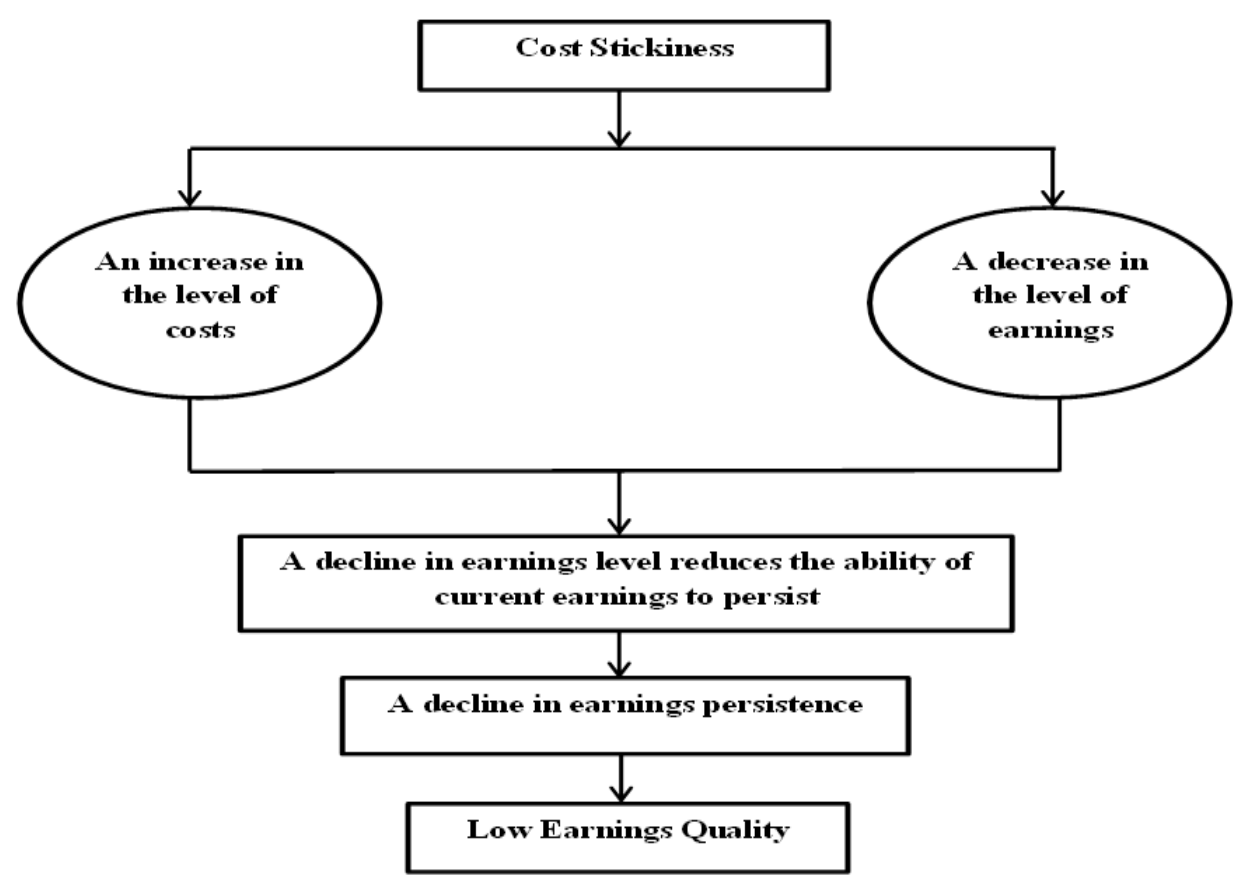

Figure 1. How cost stickiness affects earnings quality

This prediction is consistent with the results of Chung et al. (2019) which concluded that institutional monitoring decreases the degree of cost stickiness that leads to better performance in the future. Also, the predicted negative impact of cost stickiness on earnings quality is in line with the results of Silva et al. (2019) which revealed that stickiness in cost behavior has a positive impact on abnormal accruals, i.e., cost stickiness positively affects earnings management practices which means a decline in earnings quality. Consequently, the second hypothesis can be formulated as follows:

\section{H2. Cost stickiness negatively affects earnings quality.}

\subsubsection{The Effect of Cost Anti-Stickiness on Earnings Quality}

With respect to cost anti-stickiness, costs decline in the case of sales decrease more than costs increase in the case of sales increase by an equivalent amount. As a result, it is anticipated that cost anti-stickiness affects earnings quality through two interchangeable scenarios. The first scenario assumes that the magnitude of costs decline is more than the magnitude of sales decline; therefore, earnings resulting from the decrease in costs will exceed losses resulting from the decrease in sales which drives to an increase in earnings level. In other terms, anti-stickiness in cost behavior will positively affect the persistence of earnings and hence earnings quality. The second scenario supposes that the magnitude of costs decrease is less than the magnitude of sales decrease, thus, earnings resulting from the decline in costs will be absorbed by losses resulting from sales decline leading to a decline in earnings. That is to say, cost anti-stickiness will have a negative effect on earnings persistence and hence earnings 


\section{Al Macrothink \\ International Journal of Accounting and Financial Reporting \\ ISSN 2162-3082 \\ 2021, Vol. 11, No. 2}

quality. Figure 2 outlines how cost anti-stickiness affects earnings quality.

As a consequence, it is hard to forecast the impact of cost anti-stickiness on earnings quality, particularly in the absence of interest for the implications of anti-sticky behavior in the literature. Furthermore, the impact of cost anti-stickiness cannot be predicted without identifying the magnitude of the fluctuations in sales and the magnitude of adjustment costs, i.e., industry conditions. Therefore, the third hypothesis can be formulated as follows:

\section{H3. Cost anti-stickiness has a significant impact on earnings quality.}

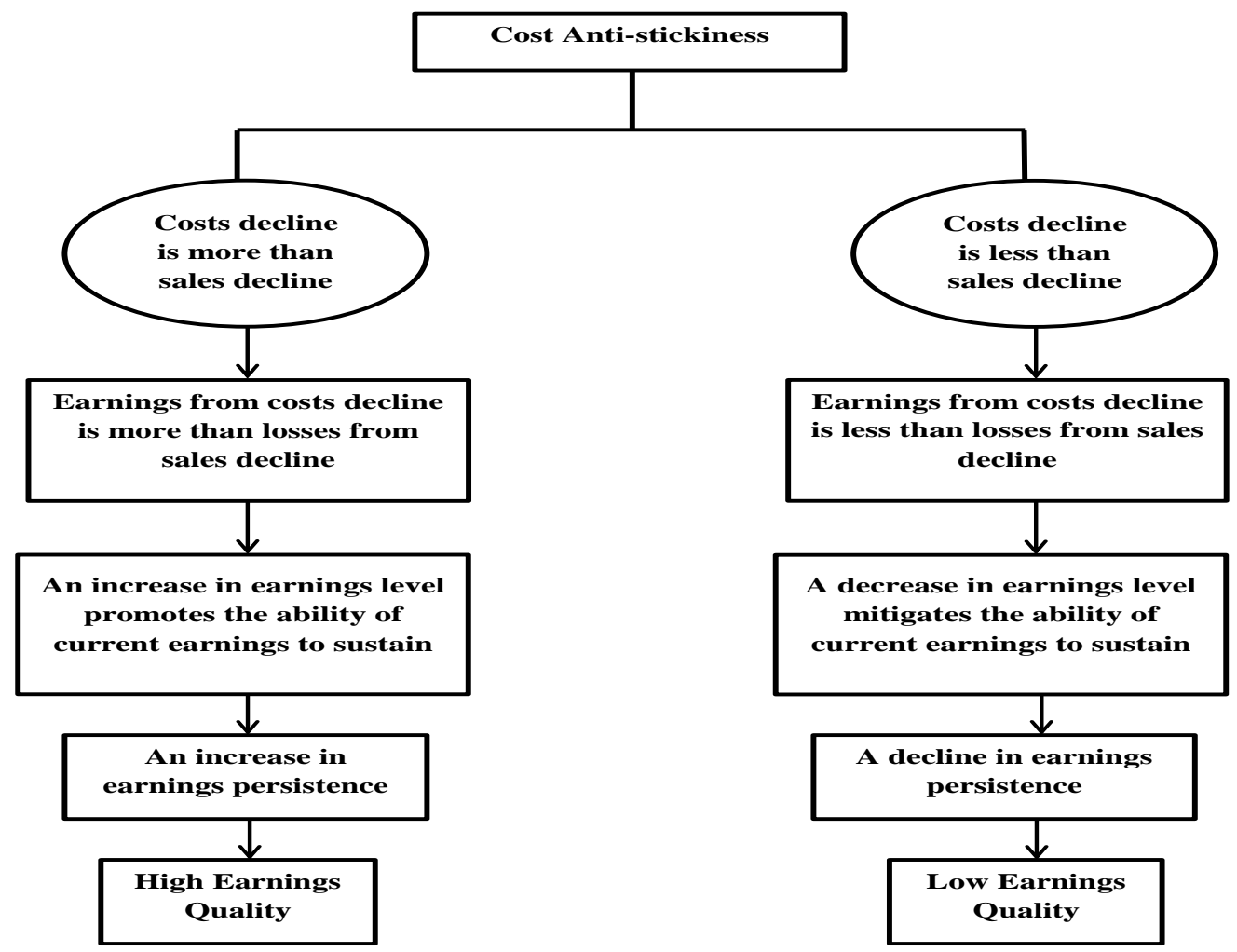

Figure 2. How cost anti-stickiness affects earnings quality

In brief, the aforesaid studies in subsections 2.1 and 2.2 highlighted some fundamental points related to sticky cost behavior, such as: (1) it is a pervasive global concept. (2) Different cost behavior from one study to another, in addition to the same type of cost behaves differently in the same study when controlling for some economic and legal factors. (3) Sticky cost behavior occurs in private and state-owned firms. (4) The factor of the managerial decisions concerning adjustment costs is the main cause of sticky cost behavior. (5) There are many factors affecting the level of stickiness or anti-stickiness such as the successive decrease in sales, type of ownership, economic growth, and political conditions. The basic limitation of these studies is that they concentrated on one or two types of costs without examining the prevalence of sticky cost behavior in total costs to alleviate managerial choices. Moreover, one limitation of the aforementioned studies in subsections 2.3 is that they examined the implications of sticky cost behavior on some aspects such as earnings forecasts, accounting 


\section{Mll Macrothink}

International Journal of Accounting and Financial Reporting

ISSN 2162-3082

2021, Vol. 11, No. 2

conservatism, and earnings management. But these studies ignore the implications of sticky cost behavior on earnings quality. Also, few studies addressed the impacts of cost anti-stickiness. Consequently, further studies will be directed to explore the implications of anti-sticky behavior and whether it has the same impact of cost stickiness or not. Therefore, the current study will examine the existence of sticky cost behavior in total costs among Egyptian sectors. Moreover, it will test the impact of the cost stickiness and cost anti-stickiness on earnings quality.

\section{Research Methodology}

\subsection{Sample and Data}

The study population includes all Egyptian listed firms during the period from 2004-2017 (Note 1) except banks and financial services firms because these firms have particular accounting rules and unique reports as well. This exclusion is in line with the literature of sticky cost behavior as the majority studies relied on non-financial firms (e.g., Banker et al., 2016; Ibrahim and Ezat, 2017; Prabowo et al., 2018; Chung et al., 2019; Hartlieb et al., 2019; $\mathrm{Li}$ and Zheng, 2020). The final research sample consists of 38 firms according to the following criteria. Firstly, all firms pulled from the population must have been listed on the Egyptian Stock Exchange during the period from 2004 to 2017. Secondly, all financial statements must have been issued in the Egyptian pound. Thirdly, firms that prepare their financial statements on 30 June have been excluded from the sample to achieve the consistency of the financial year. Fourthly, firms must have changes in the direction of sales throughout the period from 2004 to 2017.

Data for all required variables are obtained from the annual financial statements. The required data was extracted directly from income statements, balance sheets, and cash flow statements which are available on firms' websites, the Mubasher website, and Egypt for Information Dissemination Company. Firstly, to examine the existence of sticky cost behavior, firms are classified into 9 sectors as shown in the Table 1. The reason for this is keeping data homogeneity as sectors differ from each other in terms of some characteristics which affect strongly the costs response to changes in sales such as cost structure, asset intensity, employee intensity, the magnitude of sales change, and capacity utilization. Secondly, firms are divided into firms with cost stickiness and firms with cost anti-stickiness to test the effect on earnings quality in each group. 


\section{Macrothink \\ International Journal of Accounting and Financial Reporting

Table 1. Numbers of firms in each sector

\begin{tabular}{ccc}
\hline No. & Number of Firms & Sector Name \\
\hline 1 & 5 & Construction and Building Materials \\
2 & 3 & Basic Resources \\
3 & 6 & Industrial Goods, Services, and Automobiles \\
4 & 5 & Real Estate \\
5 & 5 & Food and Beverage \\
6 & 3 & Travel and Leisure \\
7 & 4 & Chemicals \\
8 & 4 & Personal and Household Products \\
9 & 3 & 9 sectors \\
\hline Total & 38 &
\end{tabular}

\subsection{Models Specification}

\subsubsection{Model (1) Investigating the Existence of Sticky Cost Behavior}

Anderson et al. (2003) provided a pioneering model to examine the asymmetric response of cost behavior to the changes in sales. The majority of literature related to investigating sticky cost behavior has used this seminal model since the model of Anderson et al. (2003) relies on the logarithmic specification and the ratio form to make the comparison among variables easier (Anderson et al., 2003). Furthermore, using the logarithmic specification and the ratio form alleviate the potential appearance of the heteroscedasticity problem (Banker and Byzalov, 2014). Therefore, the current research relies on the model of Anderson et al. (2003) to investigate the existence of sticky cost behavior among Egyptian Exchange sectors, i.e., testing the first hypothesis.

$$
\begin{aligned}
& \log \left[\frac{\operatorname{Cost}_{i, t}}{\operatorname{Cost}_{i, t-1}}\right] \\
& =\beta_{0}+\beta_{1} \log \left[\frac{\text { Sales }_{i, t}}{\text { Sales }_{i, t-1}}\right]+\beta_{2} * \text { Decrease }_{\text {Dummy }_{i, t}} \\
& * \log \left[\frac{\text { Sales }_{i, t}}{\text { Sales }_{i, t-1}}\right]+\varepsilon_{i, t}
\end{aligned}
$$

Where $\operatorname{Cost}_{i, t}$ is costs of firm (i) in the year ( $\mathrm{t}$, Cost $_{i, t-1}$ is costs of firm (i) in the year $(\mathrm{t}-1)$, Sales $_{i, t}$ is sales revenue of firm (i) in the year ( $\left.\mathrm{t}\right)$, Sales $_{i, t-1}$ is sales revenue of firm (i) in the year (t-1), and Decrease $e_{D u m m}$ i,t is dummy variable that equals (1) if sales in the year (t) less than sales in the year (t-1), and equals (0) otherwise.

The model (1) is based on the difference between sales revenue and earnings (Note 2) as a 
proxy of total costs. The current research uses this method instead of using other kinds of cost components in order to exclude managerial discretion in cost classifications (Weiss, 2010). Furthermore, investors, as Weiss (2010) proved in his results, are somewhat able to realize sticky cost behavior in total costs not in cost components. Moreover, the current paper depends on sales revenue as a proxy for activity level for some main reasons. First, sales volume data are not obtainable at the majority of financial statements (Anderson et al., 2003; Banker and Byzalov, 2014). Second, sales revenue, after deflating it to mitigate inflation, is a more convenient proxy for activity level because sales volume cannot be a comparative proxy for activity level among products and firms due to product differentiation (Banker and Byzalov, 2014). Finally, sales volume cannot be a comparative proxy for activity level between products and services; therefore, sales revenue is a more suitable proxy for activity level.

According to the notion of sticky cost behavior, costs demonstrates stickiness if the coefficient $\left(\beta_{1}\right)$ is positive and the coefficient $\left(\beta_{2}\right)$ is negative, therefore, the sum of the coefficients $\left(\beta_{1}\right)$ and $\left(\beta_{2}\right)$ will be less than the coefficient $\left(\beta_{1}\right)$. Costs displays anti-stickiness if the coefficients $\left(\beta_{1}\right)$ and $\left(\beta_{2}\right)$ both are positive, as a result, the sum of the coefficients $\left(\beta_{1}\right)$ and $\left(\beta_{2}\right)$ will be more than coefficient $\left(\beta_{1}\right)$. It should be pointed out that all variables in the model (1) are modified by using the consumer price index (CPI) (Note 3 ) to control for inflation, i.e., to remove the impact of changes in the selling price which affects directly the existence of cost stickiness and cost anti-stickiness.

\subsubsection{Model (2) Examining the Impact of Sticky Cost Behavior on Earnings Quality}

The current research tests the effect of sticky cost behavior on earnings quality, the second and third hypotheses, by establishing the model (2) following Banker and Byzalov (2014), Balakrishnan et al. (2014), Bu et al. (2015), Banker et al. (2016), Silva et al. (2019), and Fourati et al. (2020). Like Bu et al. (2015), the model (2) relies on sales levels rather than changes in sales since the dependent variable is the level of scaled earnings. Furthermore, the model (2) contains the original model of estimating earnings persistence, as a proxy of earnings quality, plus the part that reflects sticky cost behavior. It is worth noted that the existing paper will depend on earnings persistence to estimate earnings quality due to some reasons. First, persistent earnings provide a remarkable sign to accurately forecast future earnings. Second, persistent earnings are the result of basic firms' performance and hence reflect to what extent their performance is good. Third, some previous study presented evidence that earnings persistence is the most convenient attribute that points out earnings quality (e.g., Dichev et al., 2013). Fourth, earnings persistence is a time-series attribute for earnings behavior, so, it is appropriate for sticky cost behavior as sticky cost behavior also displays cost behavior across time-series. 


$$
\begin{aligned}
\text { Earnings }_{i, t}= & \beta_{0}+\beta_{1} \text { Earnings }_{i, t-1}+\beta_{2} \text { Sales }_{i, t}+\beta_{3} * \\
& \text { Decrease }_{\text {Dummy }_{i, t}} * \text { Sales }_{i, t}+\varepsilon_{i, t}
\end{aligned}
$$

Where Earnings $s_{i, t}$ is net income of firm (i) in the year $(\mathrm{t})$, Earnings $_{i, t-1}$ is net income of firm (i) in the year (t-1), Sales ${ }_{i, t}$ is sales revenue of firm (i) in the year (t), and dummy variable that equals ( 1 ) if sales in year ( $t$ ) less than sales in year (t-1), and equals (0) otherwise.

Regarding the model (2) (Note 4), earnings persistence is the slope coefficient $\left(\beta_{1}\right)$. If the value of $\left(\beta_{1}\right)$ is close to $(1)$, it indicates higher earnings persistence and hence higher earnings quality. On the other hand, if the value of $\left(\beta_{1}\right)$ is close to $(0)$, it implies lower earnings persistence, i.e., transitory earnings and thus lower earnings quality. The variables $\left(\right.$ Sales $\left._{i, t}\right)$ and (Decrease Dummy $_{i, t} *$ Sales $\left._{i, t}\right)$ capture cost stickiness and cost anti-stickiness.

\section{Results and Discussion}

\subsection{Descriptive Statistics}

Table 2 shows descriptive statistics of all variables that are employed to examine the research hypotheses. As shown in the Table 2, the mean of the logarithm of total costs throughout the sample period is (8.1868). According to the data of each sector this mean varies from sector to another as the Basic Resources sector has the highest value, while Food and Beverage sector has the lowest value. Moreover, the results show that the standard deviation of total costs is (0.75246). The maximum value of logarithm of total costs is (10.08), whereas the minimum value of total costs is (5.07). Concerning sales revenue, Table 2 indicates that the mean of the logarithm of sales revenue throughout the sample period is (8.2749). Basic and Resources sector has the highest value of the mean of sales revenue, while the Food and Beverage sector has the lowest value. Furthermore, Table 2 demonstrates that the standard deviation of sales revenue is (0.73149). Also, the maximum value of logarithm of sales revenue is (10.16), whereas the minimum value of sales revenue is (6.12). Regarding earnings, the mean of logarithm throughout the sample period is (7.4350). Basic and Resources sector displays the highest mean value, while the lowest value of the mean is shown in Healthcare and Pharmaceuticals sector. In addition, the standard deviation of earnings is (0.88381). The maximum value of logarithm of earnings is (9.47), whereas the minimum value of earnings is (5.34).

Table 2. Descriptive statistics

\begin{tabular}{ccccc}
\hline Variable & Mean & Std. Dev. & Minimum & Maximum \\
\hline Total costs & 8.1868 & 0.75246 & 5.07 & 10.08 \\
\hline Sales & 8.2749 & 0.73149 & 6.12 & 10.16 \\
\hline Earnings & 7.4350 & 0.88381 & 5.34 & 9.47 \\
\hline
\end{tabular}




\subsection{The Existence of Sticky Cost Behavior in the Egyptian Sectors}

Table 3 presents the summary statistics of the model (1) in each sector. The model (1) in all sectors is statistically significant as the p-value in all sectors is nearly (0.000). Also, it is obvious that all sectors do not suffer from the problem of autocorrelation in residuals of (OLS) regression analysis because the Durbin-Watson (Note 5) (D-W) statistic of all sectors ranges between (1.669) and (2.768). Furthermore, the problem of multicollinearity is not a matter of concern in all sectors since the highest variance inflation factor (VIF) (Note 6) is (5.086). Regarding the adjusted value of the determination coefficient (Adjusted $R^{2}$ ), the highest value is found in the Healthcare and Pharmaceuticals sector (0.924) which implies that the model explains nearly $(92 \%)$ of the variation in total costs. The lowest value of (Adjusted $R^{2}$ ) is existed in the Travel and Leisure sector (0.169) which indicates that the model explains roughly $(17 \%)$ of the variation in total costs. The low value of (Adjusted $R^{2}$ ) in the Travel and Leisure sector is consistent with the absence of sticky cost behavior in this sector as can be seen subsequently in the Table (4).

Table 3. A Summary statistics of Model (1) which examines the existence of sticky cost behavior in each sector

\begin{tabular}{|c|c|c|c|c|c|c|}
\hline No. & Names of Sectors & P-value & F-value & $\operatorname{Adj} . R^{2}$ & D-W & H-VIF \\
\hline 1 & Construction and Building Materials & 0.000 & 98.776 & 0.739 & 2.259 & 2.582 \\
\hline 2 & Basic Resources & 0.000 & 112.760 & 0.845 & 2.240 & 3.285 \\
\hline 3 & $\begin{array}{c}\text { Industrial Goods, Services, and } \\
\text { Automobiles }\end{array}$ & 0.000 & 246.134 & 0.855 & 2.256 & 3.994 \\
\hline 4 & Real Estate & 0.000 & 50.913 & 0.591 & 2.768 & 3.837 \\
\hline 5 & Food and Beverage & 0.000 & 177.608 & $\mathbf{0 . 8 3 7}$ & 2.466 & 3.021 \\
\hline 6 & Healthcare and Pharmaceuticals & 0.000 & 250.397 & 0.924 & 1.669 & 1.896 \\
\hline 7 & Travel and Leisure & 0.003 & 6.589 & 0.169 & 2.700 & 3.653 \\
\hline 8 & Chemicals & 0.000 & 92.793 & 0.769 & 1.693 & 5.086 \\
\hline 9 & Personal and Household Products & 0.000 & 21.078 & 0.495 & 2.423 & 3.164 \\
\hline
\end{tabular}

Note: H-VIF refers to highest variance inflation factor.

Table 4 summarizes the (OLS) regression results of the main coefficients of the model (1) which reflect the response of costs towards changes in sales revenues in each sector. It is 


\section{Macrothink Interational Jornal of Acesenting and Finactil Reporting ISSN 2162-3082 2021, Vol. 11, No. 2}

apparent from Table 4 that Construction and Building Materials sector displays cost stickiness because coefficient $\beta_{1}$ is positive, coefficient $\beta_{2}$ is negative, and coefficient $\beta_{1}$ is more than the combined value of $\beta_{1}$ and $\beta_{2}$. In other words, total costs increase by $0.97 \%$ and decline only by $0.40 \%$ for the $1 \%$ increase and decrease in sales, thus, total costs change asymmetrically with changes in sales reflecting the prevalence of cost stickiness. Total costs in Construction and Building Materials sector exhibit stickiness in cost behavior as a result of two potential reasons. Firstly, this sector is characterized by a high degree of employee intensity; as a consequence, dismissing employees in the case of demand decrease is costly because of severance payments. The previous interpretation is in line with the findings of prior literature of cost stickiness (e.g., Anderson et al., 2003; Yong et al., 2015; Subramaniam and Watson, 2016; Ibrahim and Ezat, 2017; Ciftci and Salama, 2018; Hartlieb et al., 2019) which concluded that firms with high employee intensity exhibit stickiness in costs. Secondly, it is projected for Construction and Building Materials sector a quick recovery if any decline occurs in demand as a result of the State's announcement of the strategic plan for urban development. This optimistic expectation drives managers to keep slack resources for present sales decline since it permits managers to reduce not only current adjustment costs that will happen when cutting unused resources but also future adjustment costs that will occur when expanding future resources. Likewise, this expectation leads managers to be more willing to increase resources when the current sales increase. Therefore, the cost response to sales increase is more than the cost response to the sales decrease causing stickiness in total costs. This result is consistent with the result of Chen et al. (2019) who concluded that managerial optimism leads to stickiness in costs.

Concerning Basic Resources sector, the results in Table 4 confirm the prevalence of cost stickiness among in the Basic Resources sector because coefficient $\beta_{1}$ is positive, coefficient $\beta_{2}$ is negative, and coefficient $\beta_{1}$ is more than the combined value of $\beta_{1}$ and $\beta_{2}$. In other words, total costs increase by $0.94 \%$ and decline only by $0.56 \%$ for the $1 \%$ increase and decrease in sales, so, total costs do not change symmetrically with changes in sales confirming the existence of cost stickiness. The probable reason for this result is that the Basic Resources sector is affected, like Construction and Building Materials sector, by the State's strategic plan to establish new urban cities and roads. Thus, the demand in this sector is forecasted to return quickly when any decrease happens in demand. This optimistic anticipation diminishes cost response to present sales decrease and raises cost response to present sales increase leading to stickiness in costs. This interpretation complies with Banker and Byzalov (2014) who interpreted how managerial optimism leads to stickiness in cost behavior. In the same context, the Real Estate sector show the existence of cost stickiness because coefficient $\beta_{1}$ is positive, coefficient $\beta_{2}$ is negative, and coefficient $\beta_{1}$ is more than the combined value of $\beta_{1}$ and $\beta_{2}$. In other words, total costs increase by $1.8 \%$ and decline only by $0.94 \%$ for the $1 \%$ increase and decrease in sales, thus, total costs change asymmetrically with changes in sales confirming the prevalence of cost stickiness.

Total costs in the Real Estate sector exhibit stickiness in cost behavior because this sector rarely faces a decline in the demand and if it happens, the demand flourishes quickly for the following reasons. Firstly, the Real Estate sector presents an essential consumer commodity 


\section{Mll Macrothink}

International Journal of Accounting and Financial Reporting

ISSN 2162-3082

2021, Vol. 11, No. 2

which is an urgent need and not just a luxury; thus, this commodity will always be required. Secondly, the Real Estate sector is considered the most secure and stable sector since it is scarcely influenced by economic disturbances. Thirdly, the Real Estate sector, like Construction and Building Materials sector, is affected by the State's strategic plan to set up modern urban cities such as the new administrative capital, new Alamein city, and some social projects for housing. Therefore, managers exhibit optimistic expectations which cause stickiness in costs for this sector. Fourthly, the degree of asset intensity in the Real estate sector leads also to stickiness in total costs. This sector has a high degree of asset intensity because it relies basically on lands and buildings, i.e., fixed assets which cause stickiness in costs. This interpretation is consistent with the findings of prior studies such as Anderson et al. (2003), Holzhacker et al. (2015), Magheed (2016), Cohen et al. (2017), Kwon (2018), and Rouxelin et al. (2018).

In the same vein, the previous results prove the prevalence of cost stickiness in the Healthcare and Pharmaceuticals sector because coefficient $\beta_{1}$ is positive, coefficient $\beta_{2}$ is negative, and coefficient $\beta_{1}$ is more than the combined value of $\beta_{1}$ and $\beta_{2}$. In other words, total costs increase nearly by $1.06 \%$ and decline only by $0.74 \%$ for the $1 \%$ increase and decrease in sales, thus, total costs do not change symmetrically with changes in sales confirming the prevalence of cost stickiness. The stickiness in total costs of the Healthcare and Pharmaceuticals sector may be related to the following reasons. Firstly, this sector offers a fundamental service which is a vital need and not just a luxury, thus, it is expected that the demand returns quickly if it decreases. Therefore, managers will be optimistic about future demand and this leads to stickiness in total costs. Secondly, firing the skillful workforce during the period of demand decline is more costly than retaining this skillful workforce because if the demand increases again, the firm will incur not only the cost of hiring but also the cost of training. This reason is in line with prior studies such as Banker and Byzalov (2014) and Hartlieb et al. (2019). Thirdly, this sector depends mainly on a variety of equipment whether to diagnoses illnesses or produce medicine, as a result, these firms have a high degree of asset intensity which increases the possibility of an appearance of stickiness in total costs. A number of studies supported this reason, for instance, Cohen et al. (2017) concluded that asset intensity increases the degree of stickiness.

Regarding the behavior of cost anti-stickiness, Table 4 demonstrates that there are two sectors display cost anti-stickiness. The first sector is the Industrial Goods, Services, and Automobiles sector as coefficient $\beta_{1}$ is positive, coefficient $\beta_{2}$ is also positive, and coefficient $\beta_{1}$ is less than the combined value of $\beta_{1}$ and $\beta_{2}$. That is to say, total costs increase by $0.69 \%$ and diminish by $0.997 \%$ for the $1 \%$ increase and decrease in sales, therefore, total costs do not change symmetrically with changes in sales denoting the prevalence of anti-sticky behavior. 
Table 4. Main Coefficients of Model (1) which examines the existence of sticky cost behavior in each sector

\begin{tabular}{|c|c|c|c|c|c|c|}
\hline No. & Names of Sectors & $\beta_{0}$ & $\beta_{1}$ & $\beta_{2}$ & $\beta_{1}+\beta_{2}$ & Cost Behavior \\
\hline 1 & Construction and Building Materials & $\begin{array}{l}-0.025 \\
(0.156)\end{array}$ & $\begin{array}{c}0.968 \\
(0.000)\end{array}$ & $\begin{array}{l}-0.567 \\
(0.001)\end{array}$ & 0.401 & Cost Stickiness \\
\hline 2 & Basic Resources & $\begin{array}{l}-0.027 \\
(0.062)\end{array}$ & $\begin{array}{c}0.944 \\
(0.000)\end{array}$ & $\begin{array}{l}-0.377 \\
(0.016)\end{array}$ & 0.567 & Cost Stickiness \\
\hline 3 & $\begin{array}{c}\text { Industrial Goods, Services, and } \\
\text { Automobiles }\end{array}$ & $\begin{array}{c}0.024 \\
(0.051)\end{array}$ & $\begin{array}{c}0.694 \\
(0.000)\end{array}$ & $\begin{array}{c}0.303 \\
(0.016)\end{array}$ & 0.997 & $\begin{array}{c}\text { Cost } \\
\text { Anti-Stickiness }\end{array}$ \\
\hline 4 & Real Estate & $\begin{array}{l}-0.122 \\
(0.138)\end{array}$ & $\begin{array}{c}1.821 \\
(0.000)\end{array}$ & $\begin{array}{l}-0.882 \\
(0.023)\end{array}$ & 0.939 & Cost Stickiness \\
\hline 5 & Food and Beverage & $\begin{array}{c}0.003 \\
(0.933)\end{array}$ & $\begin{array}{c}1.040 \\
(0.000)\end{array}$ & $\begin{array}{c}0.082 \\
(0.573)\end{array}$ & 1.122 & Insignificant \\
\hline 6 & Healthcare and Pharmaceuticals & $\begin{array}{l}-0.014 \\
(0.022)\end{array}$ & $\begin{array}{c}1.056 \\
(0.000)\end{array}$ & $\begin{array}{l}-0.320 \\
(0.051)\end{array}$ & 0.736 & Cost Stickiness \\
\hline 7 & Travel and Leisure & $\begin{array}{l}-0.012 \\
(0.895)\end{array}$ & $\begin{array}{c}0.577 \\
(0.017)\end{array}$ & $\begin{array}{l}-0.230 \\
(0.479)\end{array}$ & 0.347 & Insignificant \\
\hline 8 & Chemicals & $\begin{array}{c}0.150 \\
(0.077)\end{array}$ & $\begin{array}{c}0.729 \\
(0.017)\end{array}$ & $\begin{array}{c}1.375 \\
(0.000)\end{array}$ & 2.104 & $\begin{array}{c}\text { Cost } \\
\text { Anti-Stickiness }\end{array}$ \\
\hline 9 & Personal and Household Products & $\begin{array}{l}-0.003 \\
(0.923)\end{array}$ & $\begin{array}{l}-0.206 \\
(0.002)\end{array}$ & $\begin{array}{c}0.467 \\
(0.000)\end{array}$ & 0.261 & $\begin{array}{c}\beta_{1} \text { is negative, } \\
\text { not consistent } \\
\text { with the } \\
\text { assumption of } \\
\text { sticky cost } \\
\text { behavior }\end{array}$ \\
\hline
\end{tabular}

The second sector is the Chemical sector because coefficient $\beta_{1}$ is positive, coefficient $\beta_{2}$ is also positive, and coefficient $\beta_{1}$ is less than the combined value of $\beta_{1}$ and $\beta_{2}$. In other words, total costs increase by $0.73 \%$ and decline by $2.104 \%$ for the $1 \%$ increase and decrease in sales. As a result, total costs do not change symmetrically with changes in sales confirming the prevalence of anti-stickiness behavior in total costs. The possible cause of cost anti-stickiness in the Industrial Goods, Services, and Automobiles sector and Chemical sector is related to sales direction during the study period as it shows a propensity for the decrease. In other words, there is no fluctuation in sales and the direction of sales takes the decrease direction. Therefore, managers will have pessimistic expectations for future sales as they are certain that this decrease in sales is permanent and not transitory. This pessimistic anticipation impels managers if sales diminish in the present period to be more willing to get rid of unutilized resources to reduce not only operational costs in the present period but also 


\section{Mll Macrothink}

International Journal of Accounting and Financial Reporting

ISSN 2162-3082

2021, Vol. 11, No. 2

adjustment costs resulting from decreasing resources in the next periods. In the same sense, managerial pessimism leads to add only the essential resources to meet current demand if sales increase in the present period. Consequently, the cost response to sales increase is less than the cost response to the sales decrease causing anti-stickiness in total costs. The prior explanation is in agreement with the interpretation of previous studies (e.g., Banker and Byzalov, 2014; Venieris et al., 2015), besides, it supports the result of Chen et al. (2019) who found that managerial pessimism causes anti-stickiness in cost behavior.

Table 4 also shows that the behavior of sticky cost behavior cannot be noticed in three sectors. Firstly, total costs do not behave asymmetrically in the Food and Beverage sector. In other words, coefficient $\beta_{1}$ is significantly positive, and the whole model also is significant, nevertheless, asymmetrical behavior does not appear among firms listed in Food and Beverage sector since the main coefficient, $\beta_{2}$, which reflects the asymmetry in cost behavior is not significant. The reason for this may be related to the inelastic demand in this sector. Namely, the magnitude of sales in this sector remains constant even if the price changes. This inelastic demand in the Food and Beverage sector is directly connected with the steadily increasing in the Egyptian population and Egyptian consumption spending which is mainly directed to food and beverage.

Secondly, in the Travel and Leisure sector, coefficient $\beta_{1}$ is significantly positive, and the whole model also is significant, nonetheless, asymmetrical behavior does not appear since the main coefficient, $\beta_{2}$, which reflects the asymmetry in cost behavior is insignificant. The insignificance of $\beta_{2}$ complies with the weak explanatory power of the model as (Adjusted $R^{2}$ ) is nearly $17 \%$ which means that the model can explain only $17 \%$ of the changes in total costs. It was expected that total costs in the Travel and Leisure sector do not show asymmetric behavior since this sector depends fundamentally on temporary employment which is easy to lay off if the demand diminishes. Furthermore, this sector suffers from financial problems especially in recent years, so managers prefer to decrease costs even if by disposing of some skilled employees in demand decrease periods. This result enhances the results of Ibrahim and Ezat (2017) who found that asymmetric response of cost behavior for changes in sales is not significant for Tourism sector in Egypt.

Thirdly, Personal and Household Products sector displays an unusual result as coefficient $\beta_{1}$ is negative and statistically significant at $(-0.206)$, which implies that total costs decrease nearly by $0.21 \%$ when sales increase by $1 \%$. This result is not consistent with the assumption of the asymmetric response model of cost behavior as costs and sales should change in the same direction; consequently, the coefficient $\beta_{1}$ should be positive whether the behavior of costs sticky or anti-sticky. The coefficient $\beta_{2}$ is positive and statistically significant at (0.467), however, anti-stickiness behavior does not appear because one of the assumptions of this behavior does not exist. In other words, coefficient $\beta_{2}$ is significantly positive, and the whole model also is significant, nonetheless, anti-sticky behavior does not exist since coefficient $\beta_{1}$ is negative which contradicts with the assumptions of asymmetrical response in costs.

To sum up, sectors that display cost stickiness are Construction and Building Materials 
sector, Basic resources sector, Real Estate sector, and Healthcare and Pharmaceuticals sector, whereas Industrial Goods, Services, and Automobiles sector and Chemicals sector show the behavior of anti-stickiness. In addition, sticky cost behavior cannot be found in Food and Beverage sector, Travel and Leisure sector, and Personal and Household Products sector. These results are in line with the results of Ibrahim and Ezat (2017) who concluded that the asymmetric response of cost behavior for changes in sales does not exhibit in all Egyptian sectors. Therefore, the first hypothesis which indicates that "Total costs respond asymmetrically to the equivalent change in sales, i.e., display sticky cost behavior" can be accepted for six sectors, while it can be rejected for three sectors.

\subsection{The Impact of Sticky Cost Behavior on Earnings Quality}

\subsubsection{The Impact of Cost Stickiness on Earnings Quality}

Table 5 displays the findings obtained from the ordinary least squares regression (OLS) analysis concerning the impact of cost stickiness on earnings persistence as a proxy of earnings quality. The results imply that the model (2) is statistically significant, where the p-value is (0.000). Adjusted $R^{2}$ is (0.451), which indicates that the model explains nearly (45\%) of the variation in earnings. Additionally, VIF for $X_{1}, X_{2}, X_{3}$ are (1.060), (1.307), (1.243) respectively, thus, multicollinearity is not a problem for this model. The D-W statistic is (1.531), which means that there is no autocorrelation in residuals from (OLS) regression. Relating to the main coefficients of the model (2), the coefficient $\beta_{1}$ is significant at $(0.643)$ which indicates that earnings quality level is (0.643). The coefficients $\beta_{2}$ and $\beta_{3}$ are significant at (0.033), (-0.031) respectively which denote that cost stickiness affects the level of earnings. Moreover, the coefficient $\beta_{3}$ has a negative sign which means that stickiness in costs negatively affects earnings level, i.e., cost stickiness has a negative impact on earnings persistence and thus earnings quality.

As a result, the second hypothesis which indicates that "Cost stickiness affects earnings quality negatively" can be accepted. This finding is consistent with the theoretical prediction of the current paper; in addition, it supports the results of some of the prior studies. For example, Weiss (2010) and Ciftci et al. (2016) concluded that cost stickiness negatively affects the accuracy of earnings prediction as the correct understanding of cost behavior helps analysts to forecast earnings precisely. Also, Chung et al. (2019) revealed that the decline in cost stickiness helps firms to enhance their performance in the future.

Table 5. The impact of cost stickiness on earnings persistence as a proxy of earnings quality

\begin{tabular}{|c|c|c|c|c|c|c|}
\hline \multicolumn{7}{|c|}{ Panel A: Summary statistics of model (2) } \\
\hline P-value & F-value & $R$ & $R^{2}$ & $\operatorname{Adj} . R^{2}$ & $\mathrm{D}-\mathrm{W}$ & \\
\hline 0.000 & 62.091 & 0.677 & 0.458 & 0.451 & 1.531 & \\
\hline \multicolumn{7}{|c|}{ Panel B: Results of the main coefficients of model (2) } \\
\hline Variable & Estimator & Coefficient & Std. Error & P-value & VIF & Tolerance \\
\hline Constant & $\beta_{0}$ & 0.024 & 0.008 & 0.003 & & \\
\hline $\begin{array}{c}X_{1} \\
\text { Earning } s_{i, t-1}\end{array}$ & $\beta_{1}$ & 0.643 & 0.056 & 0.000 & 1.060 & 0.943 \\
\hline
\end{tabular}




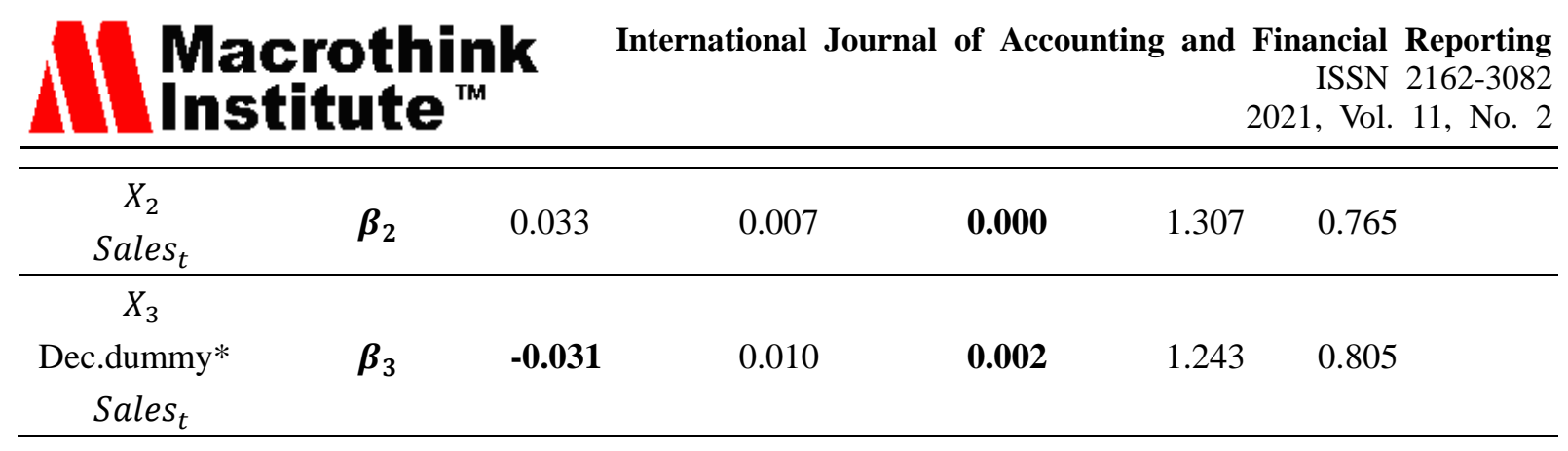

Results of Table 5 raise a further question about the level of earnings quality without controlling for cost stickiness in the original model for earnings persistence, i.e., this question is related to the accuracy of the original model of estimating earnings persistence as a proxy for earnings quality. Table 6 demonstrates the regression outputs of the original model of earnings persistence as a proxy of earnings quality without controlling for cost stickiness. The results of Table (6) show that Adjusted $R^{2}$ is (0.404) and the coefficient $\beta_{1}$ is significant at (0.699). When comparing these results with Table 5 which displays earnings quality with controlling for the impact of cost stickiness, it is found that Adjusted $R^{2}$ increases from (0.404) to $(0.451)$ when controlling for costs stickiness. In other words, the explanatory power of the model increases approximately by (0.05) when adding the impact of cost stickiness. Furthermore, the coefficient $\beta_{1}$ which reflects the quality of earnings declines from (0.699) to (0.643) when controlling for cost stickiness, i.e., the level of earnings quality decreases nearly by $(0.05)$.

Table 6. The regression results of earnings persistence as a proxy of earnings quality without controlling for cost stickiness

Panel A: Summary statistics of the standard model of earnings persistence

\begin{tabular}{|c|c|c|c|c|c|c|}
\hline P-value & F-value & $R$ & $R^{2}$ & $\operatorname{Adj} . R^{2}$ & \multicolumn{2}{|c|}{$\mathrm{D}-\mathrm{W}$} \\
\hline 0.000 & 152.209 & 0.638 & 0.407 & 0.404 & \multicolumn{2}{|c|}{1.536} \\
\hline \multicolumn{7}{|c|}{ Panel B: Results of the main coefficients of the standard model of earnings persistence } \\
\hline Variable & Estimator & Coefficient & Std. Error & P-value & VIF & Tolerance \\
\hline Constant & $\beta_{0}$ & 0.036 & 0.007 & 0.000 & & \\
\hline $\begin{array}{c}X_{1} \\
\text { Earnings }\end{array}$ & $\beta_{1}$ & 0.699 & 0.057 & 0.000 & 1.000 & 1.000 \\
\hline
\end{tabular}

This means that earnings quality level without controlling for cost stickiness is overvalued and inaccurate. This result is in line with the results of some of prior studies. For instance, Banker et al. (2016) and Fourati et al. (2020) concluded that ignoring the impact of cost stickiness in the model of Basu (1997) distorts and overvalues the estimate of accounting conservatism. Furthermore, Silva et al. (2019) revealed that the model of Dechow et al. (1995) should include cost stickiness to estimate discretionary accruals more precisely and thus estimating earnings management accurately.

In summary, the findings of the second hypothesis indicate that stickiness in cost behavior affects the level of earnings quality negatively. Moreover, the earnings quality level is more accurate after controlling for the impact of cost stickiness. As a consequence, controlling for the impact of cost stickiness in the original model of earnings persistence is substantial for precise inferences in future research on earnings quality. 


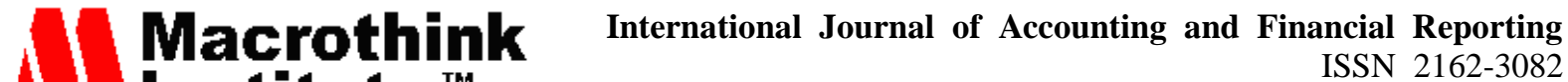 2021, Vol. 11, No. 2}

\subsubsection{The Impact of Cost Anti-Stickiness on Earnings Quality}

Table 7 provides the findings obtained from the ordinary least squares regression (OLS) analysis concerning the impact of cost anti-stickiness on earnings persistence as a proxy of earnings quality. The results denote that the model (2) is statistically significant, where the p-value is (0.000). Adjusted $R^{2}$ is (0.690), which indicates that the model explains nearly (70\%) of the variation in earnings. Furthermore, VIF for $X_{1}, X_{2}, X_{3}$ are (1.015), (1.050), and (1.040) respectively; thus, multicollinearity is not a problem for this model. The D-W statistic is (2.206), which means that autocorrelation in residuals from (OLS) regression analysis is not a matter of concern. Regarding the main coefficients of the model (2), the coefficient $\beta_{1}$ is significant at (0.904) which denotes that earnings quality level is (0.904). The coefficients $\beta_{2}$ and $\beta_{3}$ are significant at $(0.012),(-0.031)$ respectively which indicate that cost anti-stickiness affects earnings level. Furthermore, the coefficient $\beta_{3}$ has a negative sign which means that anti-stickiness behavior affects negatively earnings level, i.e., cost anti-stickiness has a negative impact on earnings persistence and hence earnings quality. This result is in line with the second scenario of the theoretical conjecture of the current paper which alleges that anti-stickiness behavior diminishes earnings. In sum, anti-sticky behavior has a negative impact on earnings persistence and thus earnings quality. Consequently, the third hypothesis which indicates that "Cost anti-stickiness has a significant impact on earnings quality" can be accepted.

Table 7. The impact of cost anti-stickiness on earnings persistence as a proxy of earnings quality

\begin{tabular}{|c|c|c|c|c|c|c|}
\hline \multicolumn{7}{|c|}{ Panel A: Summary statistics of model (2) } \\
\hline P-value & F-value & $R$ & $R^{2}$ & $\operatorname{Adj} . R^{2}$ & \multicolumn{2}{|c|}{$\mathrm{D}-\mathrm{W}$} \\
\hline 0.000 & 104.064 & 0.835 & 0.697 & 0.690 & \multicolumn{2}{|c|}{2.206} \\
\hline \multicolumn{7}{|c|}{ Panel B: Results of the main coefficients of model (2) } \\
\hline Variable & Estimator & Coefficient & Std. Error & P-value & VIF & Tolerance \\
\hline Constant & $\beta_{0}$ & 0.020 & 0.009 & 0.026 & & \\
\hline $\begin{array}{c}X_{1} \\
\text { Earning }_{i, t-1}\end{array}$ & $\beta_{1}$ & 0.904 & 0.053 & 0.000 & 1.015 & 0.985 \\
\hline $\begin{array}{c}X_{2} \\
\text { Sales }_{t}\end{array}$ & $\beta_{2}$ & 0.012 & 0.005 & 0.011 & 1.050 & 0.953 \\
\hline $\begin{array}{c}X_{3} \\
\text { Dec.dummy* }^{*} \text { Sales }_{t}\end{array}$ & $\boldsymbol{\beta}_{3}$ & -0.031 & 0.008 & 0.000 & 1.040 & 0.961 \\
\hline
\end{tabular}

Results of Table 7 lead to ask an additional question about earnings quality level without controlling for anti-sticky behavior in the original model for earnings persistence, i.e., this question is related to the precision of the original model of estimating earnings persistence as a proxy for earnings quality. Table 8 exhibits the regression results of the original model of earnings persistence as a proxy of earnings quality without controlling for cost anti-stickiness. 
Table 8 . The regression results of earnings persistence as a proxy of earnings quality without controlling for cost anti-stickiness

\begin{tabular}{|c|c|c|c|c|c|c|}
\hline \multicolumn{7}{|c|}{ Panel A: Summary statistics of the standard model of earnings persistence } \\
\hline P-value & F-value & $R$ & $R^{2}$ & $\operatorname{Adj} . R^{2}$ & \multicolumn{2}{|c|}{$\mathrm{D}-\mathrm{W}$} \\
\hline $\mathbf{0 . 0 0 0}$ & 261.043 & 0.809 & 0.654 & 0.652 & \multicolumn{2}{|c|}{2.084} \\
\hline \multicolumn{7}{|c|}{ Panel B: Results of the main coefficients of the standard model of earnings persistence } \\
\hline Variable & Estimator & Coefficient & Std. Error & P-value & VIF & Tolerance \\
\hline Constant & $\beta_{0}$ & 0.019 & 0.008 & 0.018 & & \\
\hline $\begin{array}{c}X_{1} \\
\text { Earnings }_{i, t-1}\end{array}$ & $\beta_{1}$ & 0.907 & 0.056 & 0.000 & 1.000 & 1.000 \\
\hline
\end{tabular}

The results of Table 8 display that Adjusted $R^{2}$ is $(0.652)$ and the coefficient $\beta_{1}$ is significant at (0.907). When comparing these results with Table 7 which demonstrates earnings quality with controlling for the impact of anti-sticky behavior, it is found that (Adjusted $R^{2}$ ) increases from (0.652) to (0.690) when controlling for costs anti-stickiness. It means that the explanatory power of the model increases nearly by $(0.04)$ when adding the impact of anti-sticky behavior. Moreover, the coefficient $\beta_{1}$ which reflects earnings quality exhibits a tiny decline as it changes from (0.907) to (0.904) which means that the impact of costs anti-stickiness is too limited on earnings persistence and hence earnings quality.

Overall, the findings of the third hypothesis denote that cost anti-stickiness has a negative impact on earnings quality; nonetheless, the magnitude of this impact is limited. Also, the explanatory power of the original model of earnings persistence shows an improvement when controlling for anti-sticky behavior.

\section{Robustness Analysis}

The current paper uses Sloan's model (1996) to conduct a robustness test for the impact of cost stickiness and cost anti-stickiness on earnings persistence as a proxy of earnings quality, i.e., test the findings obtained from the model (2). In Sloan's model (1996), earnings are divided into two main components cash flows and accruals. The current paper adds the part that displays cost stickiness and cost anti-stickiness to Sloan's model (1996) as follows:

$$
\begin{gathered}
\text { Earnings }_{i, t+1}=\alpha_{0}+\beta_{1} \text { CFO }_{i, t}+\beta_{2} \text { Accruals }_{i, t}+ \\
\beta_{3} \text { Sales }_{i, t}+\beta_{4} \text { Decrease }_{\text {Dummy }_{i, t}} * \\
\text { Sales }_{i, t}+\varepsilon_{i, t}
\end{gathered}
$$

Where Earnings $s_{i, t+1}$ stands for net income (i) in the year $(\mathrm{t}+1), C F O_{i, t}$ is cash flow from operating activities of firm (i) in the year (t), Accruals $s_{i, t}$ is the difference between earnings and cash flow from operating activities of firm (i) in the year (t), Sales ${ }_{i, t}$ stands for sales revenue of firm (i) in the year (t), and Decrease Dummy $_{i, t}$ is dummy variable that equals (1) if sales in year (t) less than sales in year (t-1), and equals (0) otherwise. With respect to 
Sloan's model (1996) (Note 7), earnings are more persistent when $\left(\beta_{1}\right)$ is more than $\left(\beta_{2}\right)$ and thus denote higher earnings quality. In other words, earnings show higher quality if $\left(\beta_{1}\right)$ is more than $\left(\beta_{2}\right)$.

Table (9) demonstrates that the coefficient $\beta_{1}$ is more than the coefficient $\beta_{2}$ which indicates higher earnings persistence and thus higher earnings quality. The coefficients $\beta_{3}$ and $\beta_{4}$ are significant at (0.030), (-0.022) respectively which mean that cost stickiness has a significant impact on earnings level. Moreover, the coefficient $\beta_{4}$ has a negative sign which denotes that cost stickiness negatively affects earnings level, i.e., cost stickiness has a negative impact on earnings persistence and hence earnings quality. Therefore, the result of robustness check confirms the result of the second hypothesis, i.e., cost stickiness has a negative impact on earnings quality.

Table 10 shows that the coefficient $\beta_{1}$ is more than the coefficient $\beta_{2}$ which indicates higher earnings persistence and hence higher earnings quality. The coefficients $\beta_{3}$ and $\beta_{4}$ are insignificant at $(0.007),(-0.013)$ respectively which indicate that cost anti-stickiness has no impact on earnings level. These results are close to results obtained from the comparison between Table 7 and Table 8 which denotes that cost anti-stickiness has a limited impact on earnings persistence and thus earnings quality.

Table 9. Results of Sloan's Model of the impact of cost stickiness on earnings persistence as a proxy of earnings quality

\begin{tabular}{|c|c|c|c|c|c|c|}
\hline \multicolumn{7}{|c|}{ Panel A: Summary statistics of Sloan's Model } \\
\hline P-value & F-value & $R$ & $R^{2}$ & $\operatorname{Adj} . R^{2}$ & \multicolumn{2}{|c|}{ D-W } \\
\hline 0.000 & 92.315 & 0.792 & 0.628 & 0.621 & \multicolumn{2}{|c|}{1.942} \\
\hline \multicolumn{7}{|c|}{ Panel B: Results of the main coefficients of Sloan's Model } \\
\hline Variable & Estimator & Coefficient & Std. Error & P-value & VIF & Tolerance \\
\hline Constant & $\beta_{0}$ & 0.001 & 0.009 & 0.929 & & \\
\hline $\begin{array}{c}X_{1} \\
C F O_{i, t}\end{array}$ & $\beta_{1}$ & 0.797 & 0.049 & 0.000 & 0.612 & 1.635 \\
\hline $\begin{array}{c}X_{2} \\
\text { Accruals }_{i, t}\end{array}$ & $\beta_{2}$ & 0.705 & 0.061 & 0.000 & 0.619 & 1.615 \\
\hline $\begin{array}{c}X_{3} \\
\text { Sales }_{i, t}\end{array}$ & $\beta_{3}$ & 0.030 & 0.008 & 0.000 & 0.723 & 1.383 \\
\hline $\begin{array}{c}X_{4} \\
\text { Dec.dummy* }^{*} \text { Sales }_{t}\end{array}$ & $\beta_{4}$ & -0.022 & 0.010 & 0.031 & 0.765 & 1.308 \\
\hline
\end{tabular}


Table 10. Results of Sloan's Model of the impact of cost anti-stickiness on earnings persistence as a proxy of earnings quality

\begin{tabular}{|c|c|c|c|c|c|c|}
\hline \multicolumn{7}{|c|}{ Panel A: Summary statistics of Sloan's Model } \\
\hline P-value & F-value & $R$ & $R^{2}$ & $\operatorname{Adj} . R^{2}$ & \multicolumn{2}{|c|}{$\mathrm{D}-\mathrm{W}$} \\
\hline 0.000 & 41.472 & 0.743 & 0.551 & 0.538 & \multicolumn{2}{|c|}{1.740} \\
\hline \multicolumn{7}{|c|}{ Panel B: Results of the main coefficients of Sloan's Model } \\
\hline Variable & Estimator & Coefficient & Std. Error & P-value & VIF & Tolerance \\
\hline Constant & $\beta_{0}$ & 0.028 & 0.012 & 0.024 & & \\
\hline $\begin{array}{c}X_{1} \\
C F O_{i, t}\end{array}$ & $\beta_{1}$ & 0.716 & 0.059 & 0.000 & 0.488 & 2.051 \\
\hline $\begin{array}{c}X_{2} \\
\text { Accruals }_{i, t}\end{array}$ & $\beta_{2}$ & 0.601 & 0.069 & 0.000 & 0.493 & 2.028 \\
\hline $\begin{array}{c}X_{3} \\
\text { Sales }_{i, t}\end{array}$ & $\boldsymbol{\beta}_{3}$ & 0.007 & 0.006 & 0.249 & 0.931 & 1.074 \\
\hline $\begin{array}{c}X_{4} \\
\text { Dec.dummy* }^{*} \text { Sales }_{t}\end{array}$ & $\boldsymbol{\beta}_{4}$ & -0.013 & 0.011 & 0.220 & 0.935 & 1.070 \\
\hline
\end{tabular}

\section{Conclusion}

The existing paper expands sticky cost behavior literature by providing further evidence from emerging economies namely Egypt, besides, it extents earnings quality literature by examining how sticky cost behavior, whether cost stickiness or cost anti-stickiness, affects earnings quality. To achieve this, the current paper, first, examined the prevalence of stickiness and anti-stickiness behavior among Egyptian Exchange sectors. The findings demonstrated that six of nine examined sectors exhibited sticky cost behavior. Four sectors displayed cost stickiness because of managerial optimism for future sales, besides, the high degree of employee intensity and asset intensity. Furthermore, two sectors showed cost anti-stickiness as a result of managerial pessimism which occurred as a result of the permanent decline in sales during the study period. Second, the study tested the impact of cost stickiness on earnings quality. The results indicated that stickiness in cost behavior had a negative effect on earnings quality. Furthermore, the earnings quality level without controlling for cost stickiness was overestimated and inaccurate which can cause errors in earnings forecasts as the accurate estimate of earnings quality enhances the accuracy of earnings forecasts. Third, it examined the effect of cost anti-stickiness on earnings quality. The findings showed that anti-stickiness in cost behavior negatively affected earnings quality 
but this effect was a minor effect.

The study's results revealed some implications. Firstly, managers should be cautious and take stickiness and anti-stickiness behavior into consideration when analyzing cost behavior in order to make accurate decisions, put good plans, and meet any fluctuations in the business environment. Also, managers should select a flexible cost structure that enables them to modify the committed resources without affording high adjustment costs. Secondly, when using techniques such as cost budgeting and cost volume profit analysis, cost and managerial accountants should be careful because the asymmetric response of costs implies that costs change upward and downward along two curves, not one curve as the symmetrical cost behavior alleges. Thirdly, investors and analysts should take into account that costs respond asymmetrically for sales changes when predicting earnings or estimating earnings quality. Because ignoring the impact of cost stickiness leads to overestimated and inaccurate estimates which affect stock returns negatively. Fourthly, investors and analysts should be aware of managerial choices since these choices affect cost behavior and thus affect earnings level and their quality. Finally, future research on earnings quality should pay great attention to cost stickiness in order to achieve precise inferences on earnings quality level.

The current paper has some limitations. First, this study examined the potential impact of sticky cost behavior on earnings quality only from the informative perspective, not from the opportunistic perspective. Second, the study sample did not include banks and financial services firms because of the unique nature of these firms. Third, the study sample is considered small compared to those used in developed countries, due to available data. Fourth, the current study depended only on earning persistence as a proxy for earnings quality. Therefore, future research can examine sticky cost behavior among financial Egyptian firms. Furthermore, it may be useful to investigate sticky cost behavior among non-profit Egyptian firms like Holzhacker et al. (2015). Also, future research can examine the consequences of sticky cost behavior on earnings quality from opportunistic behavior. Furthermore, one of the most interesting research opportunities in this area is using the neural networks to forecast the existence of sticky cost behavior to take proper decisions, especially which relate to pricing, keeping or reducing slack resources, and adding additional resources. Finally, future research can investigate the prevalence of sticky cost behavior and its implications under the COVID-19 crisis in order to understand and predict managers' behavior in the similar future global pandemics particularly managers' decisions concerning dismissing employees which affects unemployment rate.

\section{Acknowledgement}

The authors would like to thank the reviewers for their helpful feedback on earlier version of this manuscript.

\section{References}

Anderson, M. C., Banker, R. D., \& Janakiraman, S. N. (2003). Are selling, general, and administrative costs "sticky"? Journal of Accounting Research, 41(1), 47-63.

Balakrishnan, R., Labro, E., \& Soderstrom, N. S. (2014). Cost structure and sticky costs. 
Journal of Management Accounting Research, 26(2), 91-116.

Banker, R. D., \& Byzalov, D. (2014). Asymmetric cost behavior. Journal of Management Accounting Research, 26(2), 43-79.

, Basu, S., Byzalov, D., \& Chen, J. Y. (2016). The confounding effect of cost stickiness on conservatism estimates. Journal of Accounting and Economics, 61(1), 203-220.

, Byzalov, D., Ciftci, M., \& Mashruwala, R. (2014). The moderating effect of prior sales changes on asymmetric cost behavior. Journal of Management Accounting Research, 26(2), 221-242.

Bu, D., Wen, C., \& Banker, R. D. (2015). Implications of asymmetric cost behaviour for analysing financial reports of companies in China. China Journal of Accounting Studies, 3(3), 181-208.

Cannon, J. N. (2014). Determinants of "sticky costs": An analysis of cost behavior using United States air transportation industry data. The Accounting Review, 89(5), 1645-1672.

Chen, C. X., Lu, H., \& Sougiannis, T. (2012). The agency problem, corporate governance, and the asymmetrical behavior of selling, general, and administrative costs. Contemporary Accounting Research, 29(1), 252-282.

Chen, J. V., Kama, I., \& Lehavy, R. (2019). A contextual analysis of the impact of managerial expectations on asymmetric cost behavior. Review of Accounting Studies, 24(2), 665-693.

Cheung, J. H., Hur, K. S., \& Park, S. J. (2019). Are capitalized R\&D and expensed R\&D costs "sticky"? Korean evidence. Investment Management and Financial Innovations, 16, 89-100.

Chung, C. Y., Hur, S. K., \& Liu, C. (2019). Institutional investors and cost stickiness: Theory and evidence. The North American Journal of Economics and Finance, 47, 336-350.

Ciftci, M., Mashruwala, R., \& Weiss, D. (2016). Implications of cost behavior for analysts' earnings forecasts. Journal of Management Accounting Research, 28(1), 57-80.

\& Salama, F. M. (2018). Stickiness in costs and voluntary disclosures: evidence from management earnings forecasts. Journal of Management Accounting Research, 30(3), 211-234.

Cohen, S., Karatzimas, S., \& Naoum, V. C. (2017). The sticky cost phenomenon at the local government level: Empirical evidence from Greece. Journal of Applied Accounting Research, 18(4), 445-463.

Dai, J., Huang, R., \& Yan, Y. (2018). Cost stickiness and management's issuance of earnings forecasts. Journal of Applied Business \& Economics, 20(6), 40-56.

Dalla Via, N., \& Perego, P. (2014). Sticky cost behaviour: evidence from small and medium sized companies. Accounting \& Finance, 54(3), 753-778. 
De Sousa, E. F., \& Galdi, F. C. (2016). The relationship between equity ownership concentration and earnings quality: evidence from Brazil. Revista de Administração, 51(4), 331-343.

Ezat, A. N. M. (2014). Corporate governance ownership structure and cost stickiness: Evidence from Egypt. The Egyptian Journal for Commercial Studies, 38(4), 27-78.

Field, A. (2009). Discovering statistics Using SPSS (3rd ed.). SAGE Publications India.

Fourati, Y. M., Ghorbel, R. C., \& Jarboui, A. (2020). Sticky cost behavior and its implication on accounting conservatism: a cross-country study. Journal of Financial Reporting and Accounting, 18(1), 169-197.

Gray, D. L. (2020). Are operating lease costs sticky for retail firms?. Advances in Management Accounting, 32, 75-100.

Hartlieb, S., Loy, T. R., \& Eierle, B. (2019). Does community social capital affect asymmetric cost behaviour?. Management Accounting Research, 1-15.

Hassanein, A., \& Younis, M. (2020). Cost stickiness behavior and financial crisis: Evidence from the UK chemical industry. Corporate Ownership and Control, 17(2), 46-56.

Holzhacker, M., Krishnan, R., \& Mahlendorf, M. D. (2015). The impact of changes in regulation on cost behavior. Contemporary Accounting Research, 32(2), 534-566.

Ibrahim, A. E. A. (2015). Economic growth and cost stickiness: evidence from Egypt. Journal of Financial Reporting and Accounting, 13(1), 119-140.

(2018). Board characteristics and asymmetric cost behavior: evidence from Egypt. Accounting Research Journal, 31(2), 301-322.

\& Ezat, A. N. (2017). Sticky cost behavior: evidence from Egypt. Journal of Accounting in Emerging Economies, 7(1), 16-34.

Kama, I., \& Weiss, D. (2013). Do earnings targets and managerial incentives affect sticky costs?. Journal of Accounting Research, 51(1), 201-224.

Kamarudin, K. A., \& Ismail, W. A. W. (2014). The risk of earnings quality impairment. Procedia-Social and Behavioral Sciences, 145, 226-236.

Kitching, K., Mashruwala, R., \& Pevzner, M. (2016). Culture and cost stickiness: A cross-country study. The International Journal of Accounting, 51(3), 402-417.

Kutner, M. H., Nachtsheim, C. J., Neter, J., \& Li, W. (2005). Applied linear statistical models (Vol. 5). New York: McGraw-Hill Irwin.

Kwon, D. H. (2018). Stock Option Grants and Cost Behavior. Journal of Applied Business Research (JABR), 34(2), 265-276.

Magheed, B. A. (2016). The determines of the sticky cost behavior in the Jordanian industrial companies listed in Amman stock market. JABM Journal of Accounting-Business \& 


\section{Macrothink}

International Journal of Accounting and Financial Reporting

ISSN 2162-3082

2021, Vol. 11, No. 2

Management, 23(1), 64-81.

Prabowo, R., Hooghiemstra, R., \& Van Veen-Dirks, P. (2018). State Ownership, socio-political Factors, and labor Cost Stickiness. European Accounting Review, 27(4), 771-796.

Rouxelin, F., Wongsunwai, W., \& Yehuda, N. (2018). Aggregate cost stickiness in GAAP financial statements and future unemployment rate. The Accounting Review, 93(3), 299-325.

Silva, A. D., Zonatto, V. C. D. S., Magro, C. B. D., \& Klann, R. (2019). Sticky costs behavior and earnings management. BBR. Brazilian Business Review, 16(2), 191-206.

Sloan, R. G. (1996). Do stock prices fully reflect information in accruals and cash flows about future earnings?. Accounting Review, 289-315.

Subramaniam, C., \& Watson, M. W. (2016). Additional evidence on the sticky behavior of costs. Advances in Management Accounting, 26, 275-305.

Uy, A. O. O. (2016). Analyzing cost behavior of Philippine industrial firms. Academy of Accounting and Financial Studies Journal, 20(1), 103-113.

Venieris, G., Naoum, V. C., \& Vlismas, O. (2015). Organisation capital and sticky behaviour of selling, general and administrative expenses. Management Accounting Research, 26, 54-82.

Weiss, D. (2010). Cost behavior and analysts' earnings forecasts. The Accounting Review, 85(4), 1441-1471.

Yao, K. (2018). Cost stickiness, ownership concentration and enterprise risk-Empirical evidence from Chinese listed manufacturing companies. American Journal of Industrial and Business Management, 8(1), 163.

\section{Notes}

Note 1. It should be pointed out that the current study will depend also on data concerning the year 2003 and the year 2018 in order to calculate some variables.

Note 2. This method was used in many prior studies such as Weiss (2010), Ciftci et al. (2016), Yao (2018), and Chung et al. (2019).

Note 3. Consumer price index (CPI) were obtained from The World Bank website: https://data.worldbank.org/indicator/FP.CPI.TOTL?end=2017\&locations=EG\&start=2017\&vi ew=map

Note 4. All variables in the model (2) scaled by lagged total assets.

Note 5. Values more than 3 and less than 1 represent decidedly a matter of concern (Field, 2009).

Note 6. If VIF is more than 10, multicollinearity is a problem (Kutner et al., 2005). 


\section{Macrothink \\ International Journal of Accounting and Financial Reporting ISSN 2162-3082 2021, Vol. 11, No. 2}

Note 7. All variables in Sloan's model are scaled by lagged total assets.

\section{Copyright Disclaimer}

Copyright for this article is retained by the author(s), with first publication rights granted to the journal.

This is an open-access article distributed under the terms and conditions of the Creative Commons Attribution license (http://creativecommons.org/licenses/by/4.0/) 